\title{
The Spring Quarterly Meeting, 1993
}

The Spring Quarterly Meeting was held at the University College of Swansea on 15 and 16 April 1993 under the Presidency of Professor A. C. P. Sims.

\section{Business Meeting}

The business meeting was held on 16 April, attended by 45 Members of the College.

The meeting approved the election of following Honorary Fellows: The Baroness Faithfull; Professor Leonard I. Stein; Dr Anthony Storr, His Honour Judge Stephen Tumin; and The Lord Walton of Detchant.

\section{Minutes}

The minutes of the Winter Quarterly Meeting held at the Cavendish Conference Centre, London on 27 January 1993 were approved and signed.

\section{Report of Registrar}

Since the autumn a small working party chaired by Professor Arthur Crisp, Vice-President, has met to discuss the implications for the College of the findings of the Ashworth Inquiry into the events at that secure hospital. The working party has concentrated on the essential responsibilities of the medical practitioner and how they might be compromised by the circumstances existing at the hospital. The report is now complete and has begun its passage through the Executive and Finance Committee en route for
Council in June and thereafter for general circulation. The implications are of central concern to each member of the College and not confined to those who have to treat the most difficult in the worst surroundings.

Council has approved a report on the Position of Psychiatry in Ireland which has been developed from position statements prepared by the Irish Division following Green Papers from the Government.

The Special Committee on the Place of Prevention in Psychiatry, chaired by Professor Paykel, has now produced a report which has been approved by Council. It will shortly be available from the Publications Department.

The College has responded to the amendments to the Code of Practice of the Mental Health Act. Comments were collated and fed back.

Video recordings are increasingly used in child and adolescent psychiatric practice as well as in the Courts when children give evidence. The Section has produced a Code of Practice for such recordings, which has been approved as College policy.

The closing date for nominations for membership of Council and the Court of Electors was last Tuesday and the membership will shortly be circulated with voting papers.

It has been delightful to have been present at this meeting in Swansea.

Professor AnN Gath

Psychiatric Bulletin (1993), 17, 569

\section{Careers video competition}

A team of young psychiatrists from Guy's Hospital, London, headed by registrar Kate Lockwood, has won the $£ 5,000$ prize in a new careers video competition. Run for the first time this year by the Royal College of Psychiatrists and sponsored by Boots, the competition was designed to encourage medical students to consider psychiatry as a career. Entrants were asked to submit a video of no more than five minutes in length.

Nine entries were received from medical schools across the country. The winning entry, entitled 'The Dream Option', was devised by Kate Lockwood and produced with a team of young psychiatrists as actors. It highlights the personal qualities and interpersonal skills required of a psychiatrist and emphasises the social as well as the medical context of psychiatry.

Professor Brice Pitt, chairman of the judging panel and Public Education Director of the Royal College of Psychiatrists, said that the judges were pleased with the creativity and relevance of many of the entries and that with so much talent in evidence, it was hoped that the video competition would become a regular feature of College activity.

\section{Regional Meeting}

A regional meeting of the Royal College of Psychiatrists will take place in the Middle East from 11-13 May 1994. Further information: Dr N. Loza,

Behman Hospital, Helwan, Cairo, Egypt (fax 202 960999). 